\title{
Intraannual variation in feeding of Atlantic cod Gadus morhua: The importance of ephemeral prey bursts
}

\author{
Grønkjær, P.; Ottosen, R.; Joensen, T.; Reeve, L.; Nielsen, E.E.; Hedeholm, R.
}

Published in:

Journal of Fish Biology

Link to article, DOI:

$10.1111 / \mathrm{jfb} .14520$

Publication date:

2020

Document Version

Peer reviewed version

Link back to DTU Orbit

Citation (APA):

Grønkjær, P., Ottosen, R., Joensen, T., Reeve, L., Nielsen, E. E., \& Hedeholm, R. (2020). Intraannual variation in feeding of Atlantic cod Gadus morhua: The importance of ephemeral prey bursts. Journal of Fish Biology, 97(5), 1507-1519. https://doi.org/10.1111/jfb.14520

\section{General rights}

Copyright and moral rights for the publications made accessible in the public portal are retained by the authors and/or other copyright owners and it is a condition of accessing publications that users recognise and abide by the legal requirements associated with these rights.

- Users may download and print one copy of any publication from the public portal for the purpose of private study or research.

- You may not further distribute the material or use it for any profit-making activity or commercial gain

- You may freely distribute the URL identifying the publication in the public portal 


\title{
Intra-annual variation in feeding of Atlantic cod Gadus morhua: The importance of ephemeral prey bursts
}

\author{
Grønkjær $\mathrm{P}^{1}$, Ottosen $\mathrm{R}^{1}$, Joensen $\mathrm{T}^{1}$, Reeve $\mathrm{L}^{1}$, Nielsen $\mathrm{EE}^{2}$, Hedeholm $\mathrm{R}^{3}$
}

1 Department of Bioscience, Aquatic Biology, Aarhus University, Aarhus, Denmark

2 Institute for Aquatic Resources, Danish Technical University, Silkeborg, Denmark

3 Greenland Institute of Natural Resources, Nuuk, Greenland

Corresponding author: Peter Grønkjær, Department of Bioscience, Aquatic Biology, Aarhus

University, Ole Worms Allé 1, 8000 Aarhus C, Denmark. E-mail: Peter.Groenkjaer@bios.au.dk, ORCID: 0000-0003-1337-4661

Funding: The study was carried out with financial support from the Danish Agency for Science, Technology and Innovation as part of the Greenland Climate Research Centre.

\section{Abstract}

Seasonal prey bursts are important for the lifecycles and energy budgets of many predators. Here document the diet and, especially, the importance of the ephemeral occurrence of capelin as prey for Atlantic cod (Gadus morhua) in Godthaabsfjord, west Greenland, over an annual cycle. The cod showed clear differences in diet composition on the eleven sampling dates resulting in a spring-summer, late summer-autumn and winter cluster. Moreover, a single sampling date, May $12^{\text {th }}$, was defined by cod gorge feeding on spawning capelin, which led to average stomach contents 4.3 times higher than the average for the remaining sampling dates. Changes in nitrogen stable isotope values from April $22^{\text {nd }}$ to July $7^{\text {th }}$ in cod liver and muscle tissue was used to calculate the consumption of capelin. Based on this, the consumption of capelin varied between 538-658 $\mathrm{g}$

This article has been accepted for publication in the Journal of Fish Biology and undergone full peer review but has not been through the copyediting, typesetting, pagination and proofreading process, which may lead to differences between this version and the Version of Record. Please cite this article as doi: 10.1111/jfb.14520 
wet weight for a $1.3 \mathrm{~kg}$ cod. Using published consumption/biomass estimates and observed growth rates, the capelin intake corresponds to $10.1-33.3 \%$ of the annual food consumption and accounts for $28.1-34.5 \%$ of the annual growth of the cod. The present study documents the omnivorous feeding mode of Atlantic cod, but highlights the utilization and importance of ephemeral prey bursts for the annual energy budget of the cod. We hypothesize that access to capelin is critical for the post-spawning recovery of Godthaabsfjord cod.

Keywords: Atlantic cod, diet, capelin, stable isotopes, consumption, Greenland 


\section{INTRODUCTION}

Diet studies are crucial in order to gain insight into the ecological role of fish in the ecosystem. They are important to assess the importance of different prey species for the energy accumulation and bioenergetics of the predator, and, to reveal predator-prey interactions defining population structures for both the predator, prey and other inter-dependant species in the ecosystem (Ahlbeck et al., 2012).

Ephemeral or seasonal bursts of prey resources are a well-known ecological phenomenon (Polis et al., 1997; Naiman et al., 2002; Loreau and Holt, 2004; Willson and Womble, 2006; Yang et al., 2008). These periodical food pulses can be an important factor in supporting and structuring an ecosystem (Yang et al., 2008; McMeans et al., 2015) and play important roles in predator lifecycles (Willson and Womble, 2006; Smith et al., 2007). For example, the Ambon damselfish Pomacentrus amboinensis (Bleeker 1868), have been shown to have a higher condition, Hepato-Somatic Index and produce offspring with a better condition following the yearly mass release of propagules by reef corals (McCormick, 2003). Similar, in Atlantic cod Gadus morhua (Linneaus 1758), these short bursts of intense feeding can be important for their reproductive success and condition, and may ensure that enough energy is stored to survive starvation periods (Smith et al., 2007; van Deurs et al., 2016). Periodical high intakes of prey have been shown to be important for a wide variety of fish species to the extent that they keep their metabolism higher than needed in periods of low ey densities to be able to sustain the high digestion rates needed when a big influx of prey appears (Armstrong and Schindler, 2011).

Despite the occurrence and importance of ephemeral prey in a wide range of ecosystems, the documentation of feeding bursts on ephemeral prey are rare, likely due to the high sampling intensity needed to document these events. Smith et al. (2007) used a tri-monthly sampling scheme to document Atlantic cod gorge feeding on seasonally migrating pelagic fishes. During the events that lasted less than a month, stomach contents increased four to 10 times above the 
average. Similarly, van Deurs et al. (2016) documented the importance of the short autumn migration of Baltic herring through the Danish strait Øresund for the feeding, energy accumulation and ultimately recruitment of resident cod. Finally, anecdotal evidence suggest that cod feed intensively on capelin during their 1-2 month spawning run in West-Greenlandic fjords (Friis-Rødel and Kanneworff, 2002).

Atlantic cod is an ecological keystone species distributed all over the North Atlantic Ocean ranging from the Barents Sea to Northeast America. Atlantic cod can have a pronounced effect on the coastal ecosystems (Frank et al., 2005) and be a major predator on prey of ecological and economical value such as capelin (Mallotus villosus) and northern shrimp (Pandalus borealis) (FriisRødel and Kanneworff, 2002; Worm and Myers, 2003; Johannesen et al., 2012; Mullowney and Rose, 2014). Even though cod are generalist feeders preying on both pelagic and benthic food items (Link et al., 2009) stomach content analysis have shown them to rely heavily on pelagic lipid rich forage fishes when present (Nielsen and Andersen, 2001; Smith et al., 2007). In some locations, it is been observed that cod exploit the same food resources for most of the year and drastically change their feeding pattern when energy rich prey is abundant (Smith et al., 2007). In prolonged periods without access to such prey, these populations suffer reduced condition and reproduction potentially leading to stock collapses (Krohn et al., 1997; Marshall et al., 1999; Rose and O'Driscoll, 2002; Rideout et al., 2005).

The energy rich prey capelin found in the northern area of the cod distribution is often only seasonally available. However, the crash of some capelin populations have had pronounced effects on cod populations, subsequently showing slower growth, poorer condition and decreased breeding (Mullowney and Rose, 2014). Access to capelin is positively correlated with breeding success in Barents Sea cod (Kjesbu et al., 1998) and it has been shown that cod aggregate around and feed intensively on the dense schools of capelin during their summer feeding in the Barents Sea (Yaragina and Marshall, 2000; Bogetveit et al., 2008). The ephemeral intake of highly 
abundant prey may also be important for overwinter survival. A high intake of capelin during a period in summer and the resulting lipid storage appear to be important for the cod inhabiting the southern Gulf of St. Lawrence as they are relying on stored energy to sustain the starvation period during winter (Schwalme and Chouinard, 1999). The importance of the lipid rich pelagic prey is supported by studies on the cod carbon isotope composition with individuals exhibiting a depleted $\delta^{13} \mathrm{C}$ signal indicative of pelagic diets showing superior condition compared to cod with a more enriched $\delta^{13} \mathrm{C}$ signal reflecting a benthic diet (Sherwood et al., 2007).

In southwest Greenland, the Godthaabsfjord system $\left(64^{\circ} \mathrm{N}\right)$ harbors the largest inshore cod population in Greenland. One of the main spawning grounds of the Godthåbsfjord cod population is Kapissilit, where cod are found year round (Smidt, 1979; Swalethorp et al., 2016). This area is also a well-known spawning area for capelin during May and early June (Friis-Rødel and Kanneworff, 2002).

The aim of the present study is to investigate the intra-annual variation in Godthåbsfjord cod diet and feeding intensity with special focus on the importance of capelin to the diet. We collected cod stomachs and muscle tissue samples on eleven cruises from January $18^{\text {th }} 2010$ to January $5^{\text {th }} 2011$, and estimate the consumption of capelin based on temporal changes in stable nitrogen and carbon isotope ratios $\left(\delta^{15} \mathrm{~N}\right.$ and $\left.\delta^{13} \mathrm{C}\right)$ of the cod.

\section{MATERIALS AND METHODS}

Atlantic cod were sampled by the Greenland Institute of Natural Resources between January $18^{\text {th }}$ 2010 and July $9^{\text {th }} 2011$ at Kapisillit in the Godthåbsfjord, West Greenland, which is an important spawning ground for the Godthåbsfjord cod population (Figure 1). The inshore cod population in the Godthaabsfjord is stationary with few occurrences recorded outside the fjord (Therkildsen et al., 2013; Bonanomi et al., 2015), hence the diets reflect the local prey spectrum. Fish were 
sampled approximately monthly using hand held jig lines fished at $10-50 \mathrm{~m}$ depth. The sampled fish material was reduced by analysing only fish in the length interval $45-55 \mathrm{~cm}$ total length, which was the most common size group in the catches. This yielded 437 individuals for the stomach analysis. Sub-zero temperatures in October-March meant that fish in this period were frozen immediately after capture. In the remaining months, the fish were kept on ice to avoid stomach content degradation. Upon capture the cod were brought to the laboratory, sexed, measured to the nearest $\mathrm{cm}$ below (Total length, $\mathrm{L}_{T}$ ) and weighed to the nearest $\mathrm{g}$ (total, $\mathrm{W}_{T}$ and dressed, $\mathrm{W}_{\mathrm{D}}$ ). $\mathrm{A}$ filet of ca $10 \mathrm{~cm}$ by $5 \mathrm{~cm}$ was taken from the tail $1 / 3$ of each fish and frozen $\left(-20^{\circ} \mathrm{C}\right)$ in a ziplock bag. The stomach was removed from the esophagus to the pylorus sphincter. The cod were aged using saggital otoliths and age ranged from 3 to 7 years.

\subsection{Stomach content analysis.}

Before analysis, the stomachs were thawed but kept cold. The content was sorted and identified to the lowest taxonomical level possible. The sorted contents were individually or pooled in groups of the same species assigned to pre-weighed crucibles. Highly digested contents that were impossible to group were assigned to the category "Unknown matter".

Following the protocol in (Tarpgaard et al., 2005), samples were dried in an oven at $60{ }^{\circ} \mathrm{C}$ for at least 48 hours, with larger samples given more drying time. Samples were then cooled in a Nosiccator and weighed for dry weight after which they burned in a muffle furnace at $550{ }^{\circ} \mathrm{C}$ for least 24 hours, cooled in a desiccator, and weighed to estimate the ash content, and the ash free dry weight (AFDW).

\subsection{Stable isotope analysis}

Stable nitrogen and carbon isotope ratios $\left(\delta^{15} \mathrm{~N} \& \delta^{13} \mathrm{C}\right)$ in muscle, gonad and liver tissue were analysed in five male and five female cod from 22 April and 7 July 2010. These dates bracketed the historical spawning runs of capelin in Kapissilit. Muscle, gonad and liver tissues were dried at $60{ }^{\circ} \mathrm{C}$ 
for approximately 5 days and control weighed to make sure all water was evaporated. The samples were then kept in a desiccator until they were cold and then weighed. Liver and gonad samples were lipid extracted with a 2:1 chloroform/methanol solution following Doucette et al. (2010). Gonad samples were treated with $2 \mathrm{ml}$ solution for 24 hours in a closed tube. The solution was then removed with a pipette and the samples were rinsed with another $2 \mathrm{ml}$ of solution before being left for 24 hours in the fume hood for the remaining solution to evaporate. The liver samples were high in lipids so they received three treatments with $5 \mathrm{ml}$ of solution each running 24 hours before being rinsed and left to evaporate for 24 hours in the fume hood. After lipid extraction, the samples were dried at $60{ }^{\circ} \mathrm{C}$ for 24 hours and then stored in a desiccator to keep them free of moisture. Muscle tissues were not lipid extracted because cod muscle contain low and relatively stable amounts of lipid (Sherwood and Rose, 2005).

Additionally, ten capelin and three euphausiids samples from May were collected from cod stomachs. These prey samples were dried for 5 days at $60^{\circ} \mathrm{C}$ and then lipid extracted with $2 \mathrm{ml}$ 2:1 chloroform/methanol solution for 24 hours before being rinsed with solution and left in the fume hood for 24 hours to evaporate. After treatment, duplicates of all samples were powdered and packed in tin boats for stable isotope analysis.

Duplicate samples of each individual and tissue were analyzed at the Center for Geomicrobiology, ^ rhus University, Denmark using a Thermo Scientific elemental analyzer, Flash EA 1112 HT and Thermo Scientific IRMS, Delta plus V with a Thermo Scientific Conflo IV interface. The $\delta^{15} \mathrm{~N}$ and $\delta^{13} \mathrm{C}$ values were normalized using regressions of analyses values from the standards acetanilide $\left(\delta^{15} \mathrm{~N}\right.$ : $1.15 \%$ ), USG40 ( $\delta^{15} \mathrm{~N}:-4.5 \%$, $\delta^{13} \mathrm{C}:-26.39 \%$ ), and sucrose $\left(\delta^{13} \mathrm{C}:-10.45 \%\right.$ ). Moreover, for each 10 samples, three control samples of a known in-house standard (Gelatine A) were included to correct for drift within and between rounds of analyses. The mean of the duplicate samples was used in the data analysis. 


\subsection{Data analysis}

A GLM on size-specific log transformed AFDW of total stomach content by sex and months were conducted using R (R Core Team, 2018). Stomachs labelled "empty" but containing heavily digested matter were also included in this dataset. In total, stomach content data from 430 of the 437 cod were included.

The data was also analyzed by cluster analysis using the program Primer version 5 (Primer-E Ltd.) producing a cluster plot based on Brey-Curtis similarities of untransformed prey AFDW.

Shannon diversity indexes were calculated for each month using equation 1:

$H=\sum_{i=1}^{n} p i * \ln \left(\frac{1}{P i}\right)$ equation 1 where $\mathrm{n}$ is the number of prey groups and $\mathrm{Pi}$ is the proportion of prey group $i$ in stomach based on AFDW for the particular sampling date.

We used the change in stable nitrogen and carbon isotope values $\left(\delta^{15} \mathrm{~N}\right.$ and $\left.\delta^{13} \mathrm{C}\right)$ in cod muscle, gonad and liver tissue to estimate the cod consumption (i.e. assimilation) of capelin during the spawning run. The base of the model is the equation for isotopic change through growth and metabolic turnover by Fry and Arnold (1982):

$\delta_{t}=\delta_{f}+\left(\delta_{i}-\delta_{f}\right) *\left(W_{t} / W_{i}\right)^{c} \quad$ equation 2

Where $\delta_{t}$ is the isotopic value at time $t ; \mathrm{W}_{\mathrm{i}}$ is the initial weight of the consumer and $\mathrm{W}_{\mathrm{t}}$ is the weight at time t. $\delta_{i}$ is the initial isotopic value and $\delta_{f}$ is the isotopic value of the prey plus a given trophic enrichment. $c$ is the relative contribution from metabolic turnover and growth to the isotopic change. Isotopic change only due to growth would correspond to a c value of -1 , while lower c values indicates a higher contribution from metabolic turnover. Lambert and Dutil (2001) 
reported food conversion efficiencies of ca 0.2 for cod of the same size range as the present. Assuming a $20 \%$ loss of ingested material as excretory products yields a net growth efficiency (NGE $=$ Growth/Assimilated food) of 0.4. This NGE corresponds to a $c$ of ca -2.6 , which, as expected, is slightly higher than values estimated for smaller faster growing cod by Ankjærø et al. (2012).

To estimate the amount of capelin assimilated during the May-June spawning run, we set $\delta_{i}$ to the isotope value of the cod tissue prior to feeding on capelin (22 April) and $\delta_{t}$ to the value recorded after feeding on capelin ( $7 \mathrm{July}$ ). $\delta_{f}$ was set to the equilibrium isotope value of cod feeding on a mixture of capelin ( $80 \%)$ and euphausiids (20\%). This was calculated as the weighted isotopic value of capelin and euphausiids recovered from stomach plus 3.2\%o trophic enrichment for $\delta^{15} \mathrm{~N}$ and 1.5\% for $\delta^{13} \mathrm{C}$ (Sweeting et al., 2007a; Sweeting et al., 2007b).

$W_{i}$ was set to an the average total weight of cod on April $22^{\text {nd }}$ prior to feeding on capelin $(1.3 \pm 0.2$ (SD) $\mathrm{kg}, \mathrm{n}=52$ ). Equation 3 was then solved for $\mathrm{W}_{t} . \mathrm{W}_{i}$ was subtracted from $\mathrm{W}_{t}$ to give the growth corresponding to the observed isotope shift. This growth was then divided by the gross conversions efficiency to yield the estimate of consumed prey in gram wet weight. Finally, the contribution of capelin was calculated as the $80 \%$ of the consumed prey following the observed weighted contribution of capelin and euphausiids.

The capelin consumption estimated using this isotope based method was compared with estimates from published gut evacuation experiments and consumption/biomass (Q/B) ratios. The percentage contribution of capelin to the annual food intake was estimated by dividing estimated capelin intake with the estimated total consumption based on the $Q / B$ ratios and a mean weight of the cod of $1.3 \mathrm{~kg}$.

The annual growth of the age-classes 3 to 6 years, which were the ages represented in the samples, was calculated using age-specific weight of these age classes obtained from samples 
collected between April $22^{\text {nd }}$ and July $7^{\text {th }}(n=284)$ and calculating growth between subsequent age-classes. The growth corresponding to the ingestion of capelin was calculated as $0.8 *\left(\mathrm{~W}_{\mathrm{t}}-1300\right.$ g) to account for the $20 \%$ contribution of euphausiids to the diet during the period. This estimate was then divided by the annual growth to estimate the relative contribution of growth fueled by the ingestion of capelin.

\section{RESULTS}

The 437 cod investigated consumed 31 prey species and higher taxonomic groups with a total prey biomass of $593.6 \mathrm{~g}$ AFDW (Table 1). Thirty-two percent of the stomachs were empty or contained only highly digested "Unknown material" in which case they were also referred to as empty. The percentage of empty stomachs varied between zero on January $18^{\text {th }} 2010$ to 100 on January $5^{\text {th }}$ 2011 and was generally higher during winter and early spring (Table 1). The high feeding incidence on January $18^{\text {th }} 2010$ was related to massive occurrence of squid from the order Teuthida in the diet. On January $5^{\text {th }} 2011$, the sampled cod only contained unknown material.

The percentage of females in the samples was low (14-37\%) between April and June, whereas they represented approximately $50 \%$ of the sample in the remaining months (Figure $2 \mathrm{a}$ ). Prey diversity as indicated by the Shannon index calculated on biomass proportions ranged from 0.29 on May $1^{\text {th }}$, where the cod primarily fed on capelin, to 1.83 on August $23^{\text {rd }}$ (Figure $2 b$ ). The highest prey diversity was recorded in summer and autumn and the diversity index was above one on all sampling occasions except May $12^{\text {th }}$ and June $7^{\text {th }}$. Overall, $69 \%$ of the identified prey AFDW was from pelagic prey species or groups (see Table 1 for identification of pelagic prey). There was an inverse relationship between prey diversity and the proportion of pelagic prey, seen as a low prey species diversity when the cod were feeding on pelagic prey. The highest proportion of pelagic prey was found in winter and spring $(0.8-0.97)$ with exception of April $22^{\text {nd }}(0.44)$, whereas the 
proportion varied between 0.07 and 0.47 during July to November. Summed over the year $69 \%$ of the diet AFDW consisted of pelagic prey.

The average stomach content varied considerably between sexes and across the year (Figure $2 c$ ). The average $( \pm \mathrm{SE})$ stomach content of females was $1.44 \pm 0.22 \mathrm{~g}$ AFDW $/ \mathrm{kg}$ dressed weight and $0.99 \pm 0.14 \mathrm{~g} \mathrm{AFDW} / \mathrm{kg}$ dressed weight for males. A two-way GLM (logit link) of stomach content with sex and sampling date showed that males on average had less food in the stomachs $(t=3.0$, $\mathrm{P}=0.003)$. There were also significant differences between sampling occasions. Fish from May $12^{\text {th }}$ had more food and fish from January $5^{\text {th }}$ on average had less food in their stomachs than at the other sampling occasions (May $12^{\text {th }}: t=3.2, P=0.001$; January $5^{\text {th }}: t=5.5, p<0.001$ ). The stomach contents on May $12^{\text {th }}$, which primarily contained capelin, was 4.3 times higher than the average for the remaining sampling dates; and made up $30 \%$ of the summed stomach contents over the year for females and $26 \%$ for males. The average stomach content on this date. The three most abundant prey groups: capelin, the euphausiid Thysanoessa raschii and the squids (Teuthida) contributed $189.8,104.2$ and $60.7 \mathrm{~g}$ AFDW to diet, which combined corresponds to $60 \%$ of the diet biomass over the year.

There were clear seasonal patterns in the diet composition. The hierarchical cluster analysis based on Bray-Curtis similarities of untransformed AFDW showed distinct groupings of the sampling Nates. The May $12^{\text {th }}$ diet was dominated by capelin and was distinct from three other clusters comprised of the spring-summer dates (April to July), the late summer-autumn dates (AugustNovember) and finally the winter dates (December and January)(Figure 3). Bivalves and the Gammaridae contributed to the diet primarily in the late summer and autumn cluster and the squids were important in winter. There were also prey groups that contributed throughout the year. Polychaetes of the family Nerididae and the T. raschii contributed to the diet on all sampling occasions expect January $5^{\text {th }}$. The Nerididae were especially important during the autumn, 
whereas T. raschii was most important during spring and summer. Similarly important throughout the year were the Echinodermata, especially the holothurians P. calcigera and C. laevis.

We analysed the change in cod tissue isotope values from April $22^{\text {nd }}$ to July $7^{\text {th }}$ to estimate the consumption of capelin during their spawning run. The mean nitrogen and carbon isotopic values of capelin recovered from the stomachs of the cod were $13.9 \pm 0.2 \%$ (SE) and $-19.0 \pm 0.1 \%$ (SE) \%o for $\delta^{15} \mathrm{~N}$ and $\delta^{13} \mathrm{C}$ and $12.2 \pm 0.1 \%$ (SE) and $-19.4 \pm 0.1 \%$ (SE) for euphausiids. This yielded equilibrium values $\left(\delta_{f}\right)$ of $16.8 \% \circ \delta^{15} \mathrm{~N}$ for and $-17.8 \%$ ofor $\delta^{13} \mathrm{C}$. The overall mean isotope values of the cod tissues on 22 April prior to feeding on capelin was $14.7 \%$ ofor $\delta^{15} \mathrm{~N}$ and $-19.3 \%$ for $\delta^{13} \mathrm{C}$. On the 7 July, these values had increased to $15.1 \%$ and $-19.2 \%$ (Table 2 ). Unfortunately, the equilibrium value of $\delta^{13} \mathrm{C}$ was too close to the initial carbon isotope value of the cod tissues to yield robust estimates of isotopic change in the carbon isotope values needed to calculate consumption.

The sex and tissue specific increase in $\delta^{15} \mathrm{~N}$ varied between 0.3 and $1.2 \%$, which led to estimates of $W_{t}$ ranging from 1434.5 to $1629.8 \mathrm{~g}$, equivalent to a weight increase of 134.5 to $329.8 \mathrm{~g}$ per cod over the period Table 2). For the female gonad, there was a decrease in $\delta^{15} \mathrm{~N}$ of $0.9 \%$ rendering calculations using this tissue impossible. The estimates of capelin consumption were very consistent between muscle and liver tissue and ranged from 538.0 to $658.9 \mathrm{~g} \mathrm{WW}$ for a $1.3 \mathrm{~kg}$ cod. In contrast, the male gonad based estimate was $1319.5 \mathrm{~g} \mathrm{WW.}$

Consumption biomass ratios ( $\mathrm{Q} / \mathrm{B}$ ) for cod from the literature vary between 1.41-4.55 (Palomares and Pauly, 1989; Pauly, 1989) although values up to 10.7 has been reported for juvenile cod (Hawkins et al., 1985). The former range of Q/B suggest that the $1.3 \mathrm{~kg}$ cod would consume between $1.8-5.9 \mathrm{~kg}$ food per year, in which case the capelin would contribute between $10.1-$ $33.3 \%$ of the annual food consumption using an average value of $598.5 \mathrm{~g}$ capelin consumed. 
The modelled growth (Table 2) from April $22^{\text {nd }}$ to July $7^{\text {th }}$ obtained using equation 2 was between 134.5-164.9 $\mathrm{g}\left(\mathrm{W}_{\mathrm{t}}-1300 \mathrm{~g}\right)$. With capelin contributing $80 \%$ of the intake during that period, this corresponds to 107.6-131.9 g growth that can be attributed to capelin ingestion. In comparison, the average annual growth of the cod in was $382.2 \mathrm{~g}$ between age 3 and 6 , which suggest that the capelin-fuelled growth from late April to early July accounts for ca $28.1-34.5 \%$ of the annual growth. 


\section{DISCUSSION}

The present study documents the generalist feeding mode of Atlantic cod, and highlights the utilization and importance of ephemeral prey bursts for the annual energy budget of the cod.

\subsection{Atlantic cod diet}

Based on the large body on literature on Atlantic cod feeding there appear to be three major determinants of cod diet composition; 1) ontogeny and size, 2) coastal versus offshore occupancy and 3) season. We expect that these three determinants also influence the diet composition of the cod in Godthaabsfjord over an annual cycle.

The fish in the present study are representative of medium sized, coastal cod and our data cover their diet through a whole year. Our data from Godthaabsfjord confirms the generalist and omnivorous feeding mode of cod observed in numerous earlier studies (see review by Link et al. (2009)). Overall, the diet resembles what is found in similar coastal arcto-boreal ecosystems where the cod diet consists of a mixture of benthic and pelagic prey (e.g. Faroe Bank: Magnussen (2011); Newfoundland: Knickle and Rose (2014); Norway: Enoksen and Reiss (2018); Sweden: Mattson (1990); Greenland: Nielsen and Andersen (2001). The proportion of fish with both prey types in the diet varied between 4 and $28 \%$. Hence, the mixture of pelagic and benthic prey observed at each sampling time was primarily the result of individual fish focusing on either pelagic or benthic prey and indicates that individuals tend to focus feeding in one specific habitat even in these relatively shallow coastal areas.

The summed proportion of pelagic prey was $69 \%$ illustrating the importance of these prey groups even in a coastal and shallow $(<100 \mathrm{~m})$ fjord section. The pelagic prey was dominated by only three groups, with the euphausiid T. raschii, occurring in the diet year round, but especially important in spring and early summer; while occurrence of capelin and squids were restricted to the spring and winter period, respectively. Together they constituted $97 \%$ of the pelagic prey of 
cod. The importance of euphausiids is well documented in offshore, coastal and fjord systems and across a broad range of cod sizes (Dalpadado and Bogstad, 2004; Pálsson and Björnsson, 2011; Knickle and Rose, 2014; Hedeholm et al., 2017; Enoksen and Reiss, 2018). The inclusion of this group throughout the year indicates that feeding on euphausiids is not only due to lack of larger, more suitable prey items, but likely also reflects their high abundance, which compensate for their small size relative to other prey. Moreover, the ingestion of euphausiids may be underestimated due to the rapid digestion of small prey items compared to e.g. fish and larger crustaceans (Knutsen and Salvanes, 1999). In line with the observations in cod, Grønkjær et al (2019) found that euphausiids contributed more than $95 \%$ of the prey biomass of capelin in spring (May) in Godthaabsfjord further pointing to the keystone role of euphausiids in arcto-boreal marine ecosystems.

The benthic prey consisted of a diverse mixture of species of bivalves, gastropods, polychaets, crustaceans and echinoderms. The group was dominated by polychaetes of the family nereididae, and the two holothurians Pentamera calcigera and Chiridota laevis, which together made up 66\% of the benthic prey biomass. While polychaetes are commonly found in the diets of cod (e.g. Magnussen (2011); Enoksen and Reiss (2018)), they seldom make up substantial proportions of the diet, even when they are found in high abundances in co-occurring species such as Greenland cod (Gadus ogac) (Knickle and Rose, 2014). An important exception is the study of Mattson (1990) who found that polychaetes contributed $22 \%$ of the cod diet mass in a soft bottom Swedish fjord. The high occurrence of polychaetes in the diet of cod is likely dependent on the presence of soft bottom sediment. Furthermore, the occurrence and importance of the polychaetes is prone to underestimation due to the rapid digestion of prey without hard tissue (Sheffield et al., 2001).

The high proportion of holothurians (10\%) in the diet of the cod is uncommon, but also observed by Nielsen and Andersen (2001) in the same area. Enoksen and Reiss (2018) found holothurians to contribute $9.4 \%$ of the diet mass at one sampling site in the Norwegian Saltfjord - Skjerstadfjord 
fjord system. Smith et al. (2007) also found holothurians to contribute significantly to the diet of cod in a nearshore region of Cape cod. However, the contribution was highly variable over time and primarily important in the autumn and winter period. Whether holothurians are absent from the many other studies of cod diet or included as rare prey item in an "Other" group is not clear, but they appear to be important in some nearshore areas.

While the mix of benthic and pelagic prey in the cod diet can be driven by different feeding habitats and the availability of the different prey groups there may also be a physiological driver. van Deurs et al. (2016) found that while gorge feeding on migrating herring provided cod with large lipid reserves, the herring were lacking important fatty acids (e.g. arachidonic acid) for cod reproduction (Røjbek et al., 2014), which were provided by benthic crustaceans. Røjbek et al. (2012) also found lower levels of arachidonic acid and astaxanthin levels in herring and sprat than in the benthic isopod Saduria entomon and suggested that lack of S. entomon in the diet may affect the reproduction of Baltic cod. The extent to which this mixture of benthic and pelagic prey is key to a diet containing the necessary components for enhanced growth and reproduction should be investigated as an additional determinant of prey selection in wild fishes.

\subsection{Temporal variation in diets}

The monthly composition of prey items revealed well-defined seasonal clusters consisting of a spring-summer, an autumn and a winter cluster. Separated from these was the May $12^{\text {th }}$ sampling where capelin dominated the diet.

The spring-summer cluster was characterised by a low prey biomass in the stomachs dominated by euphausiids supplemented with a high diversity of other minor prey items. Due to the importance of euphausiids, the Shannon-diversity was lower than during the autumn and the proportion of pelagic prey was higher than in most other months. Temporally, the spring-summer 
cluster covers the period when the cod prepare for spawning that occurs in late April through May (Swalethorp et al., 2016). The pelagic spawning behaviour may be implicated in the more pelagic feeding and the generally lower diet biomass, although several studies (Michalsen et al., 2008; Krumsick and Rose, 2012) and the May $12^{\text {th }}$ sampling show that cod are feeding during spawning. The influence of spawning on diet composition is further supported by the finding that the first post-spawning sampling in July is a transition to the autumn cluster and shows increasing prey diversity and an increasing proportion of benthic prey.

The autumn cluster is almost entirely defined by benthic prey items (86-93\%) and a high diversity of prey items where especially polychaetes and holothurians contribute to the biomass. The high contribution of short-lived invertebrates is likely linked to their population dynamics and the increased production fuelled by detritus from the spring-summer phytoplankton blooms leading to increased biomasses of the benthic invertebrate fauna (Blicher et al., 2010; Kuklinski et al., 2013; Swalethorp et al., 2014; Juul-Pedersen et al., 2015).

The winter cluster was made up of the January 2010 and December 2010 samples, i.e. samples separated by eleven months. January 2011 samples could not be included in the analysis as they were entirely composed of undeterminable digested matter. This cluster was characterized by the importance of squids (Teuthida) in the diet. The only other sampling dates with squids were April 7 th and August $23^{\text {rd }}$, but these contributed less than $4 \%$ of the summed mass of squids. Magnussen (2011) also documented the importance of squids (Loligo forbesi) for the Faroe Bank cod, and stressed that the occurrence of these varied considerable among years. The importance of the squid in the winter diet suggests that they appear in very large quantities. While the digested squid could not be determined to species, the most like candidate is Gonatus fabricii based on trawl catches in the area (Frandsen and Wieland, 2004) and the estimated size of the ingested squid. The ingested squid are small juveniles ca 10-60 $\mathrm{mm}$ and based on estimated growth rates of 4-8 $\mathrm{mm} /$ month suggesting that they could be the result of hatching occurring in autumn as 
reported for the Disko Bay area north of Godthaabsfjord (Kristensen, 1977). That squids are basically limited to the winter diets is intriguing as $10-40 \mathrm{~mm}$ juvenile $\mathrm{G}$. fabricii have been observed in large quantities on the shelf outside Godthaabsfjord in August and in November (Piatkowski and Wieland, 1993). One explanation could be that juvenile squid migrate from the shelf to the fjord in winter. However the finding of a few larger (ca $60 \mathrm{~mm}$ ) squids in the diet in April and August suggest that they are present in the fjord throughout the year. The lack of a more pronounced inclusion in the diet could thus also be due to lack of overlap in the vertical distribution if larger squid primarily are occupying the deeper areas of the fjord (Bjørke, 2001), or alternatively that they are less preferred than other prey items and only included when these other items are scarce. Further knowledge of biology of the squids in the Greenlandic coastal and fjord area is much need to evaluate their trophic importance.

\subsection{The ephemeral consumption of capelin}

In May capelin was the all dominant prey and their availability increased the diet biomass four-fold over the average of the other sampling dates. The importance of capelin for cod diet and energy budget is well established in both coastal and offshore migrating populations (Bogetveit et al., 2008; Link et al., 2009). Capelin was only found in $40 \%$ of the cod on May $12^{\text {th }}$, the remainder were primarily feeding on euphausiids. Females feeding on capelin had, on average, smaller gonads $1108 \pm 17 \mathrm{~g} \mathrm{WW}, \mathrm{SE})$ than females not feeding on capelin (160 $\pm 37 \mathrm{~g} \mathrm{ww}, \mathrm{SE})$ suggesting that cod females closer to spawning eat less capelin. The same pattern was not evident for male cod. It is interesting that capelin diets were restricted to the sampling in May and a single occurrence on April $7^{\text {th }}$. The timing coincides with the peak capelin spawning in the nearshore spawning locations in Kapisillit (Friis-Rødel and Kanneworff, 2002; Hedeholm et al., 2010). However, the capelin are typically found in the vicinity of the spawning areas over a longer period in preparation for spawning, with a size and sex related differences in the temporal occurrence at the spawning sites 
(Vandeperre and Methven, 2007; Maxner et al., 2016), hence, it is surprising that capelin were absent from the diet in late April and early June.

While stomach content analysis provides a good overview of the species composition in the diet on a given sampling date, it is not useful for obtaining estimates of ingestion rates and hence the importance of the different prey species. To estimate the ingestion of capelin during their spawning run in May-June, we therefore analysed the change in nitrogen and carbon isotopic values of the cod tissues brought about by the pronounced change in diet, and modelled the ingestion of capelin needed to incur this isotopic change. For this method to yield robust estimates of ingestion, the isotope values of the new diet must be so different from the consumers' isotope value that it induces a significant change in these values. It was not possible to obtain robust estimates from the carbon isotope analysis because the $\delta^{13} \mathrm{C}$ equilibrium value of cod feeding on capelin was similar to the starting value of the cod tissue $\delta^{13} \mathrm{C}$, i.e. the switch to a capelin based diet would not incur a change in the cod tissue $\delta^{13} \mathrm{C}$ values. $\delta^{13} \mathrm{C}$ values of consumers in coastal marine systems are primarily controlled by whether the carbon in the food web supporting the consumer is derived from benthic or pelagic primary producers (Newsome et al., 2007). The importance of pelagic prey outside the period where cod fed on capelin therefore meant that the cod tissues did not undergo a change in the $\delta^{13} \mathrm{C}$ values in response to capelin feeding. In contrast, $\delta^{15} \mathrm{~N}$ is related to the trophic level of the consumer and increases with ca $3.2 \%$ from the diet to the consumer (Sweeting et al., 2007a). Hence, the changes in $\delta^{13} \mathrm{C}$ and $\delta^{15} \mathrm{~N}$ following a diet shift are not necessarily parallel.

For nitrogen, the approach yielded remarkably similar results (ingestion: $538.8-658.8 \mathrm{~g}$ WW capelin), when applied to female and male muscle and liver tissues. When applied to the gonad tissues, the ingestion estimate was ca two times higher for males, whereas a decreased isotopic value for female gonads made the calculation impossible. We speculate that the rapid change in 
the size and composition of the male and female gonads from pre- to post-spawning conditions influenced the nitrogen isotopic values of the gonads and rendered the calculations unreliable.

The estimated capelin consumption compares favourably with estimates of ingestion of prey from other studies. The equation by Waiwood et al. (1991) which is based on cod feeding on shrimp (Pandalus montagui) yields a daily prey intake of 11.3 and $16.0 \mathrm{~g} \mathrm{WW}$ in a $1.3 \mathrm{~kg}$ cod at 1 and $4{ }^{\circ} \mathrm{C}$, respectively. The gut evacuation model by Temming and Herrmann (2003) with capelin specific parameter settings yielded daily intake of capelin of $10.4 \mathrm{~g} \mathrm{WW}$ assuming a temperature of $2.5^{\circ} \mathrm{C}$ and an average stomach content of $24.3 \mathrm{~g} \mathrm{WW}$ capelin calculated as average AFDW of capelin divided by an AFDW to WW ratio of 0.15 . This calculation of daily capelin ingestion suggests that the cod are feeding on capelin at this level for approximately two months (total ingestion / daily ingestion: $538.8 \mathrm{~g} / 10.4 \mathrm{~g} \mathrm{~d}^{-1}=52$ days; $658.8 \mathrm{~g} / 10.4 \mathrm{~g} \mathrm{~d}^{-1}=63$ days) which is comparable with the observed time span of capelin occurrence near the spawning areas in Godthaabsfjord. However, we only observed substantial capelin in the diet on $12^{\text {th }}$ May and a small contribution on $7^{\text {th }}$ April. We propose that the feeding on capelin in a small area such as Kapisillit may be a very dynamic process with day-to-day variations in the intake driven by the small-scale migration behaviour and hence availability of the capelin.

The contribution of capelin to the annual prey consumption was between 10.1 and $33.3 \%$, when nctimated based on published Q/B values (range 1.41-4.55). The average consumption estimate based on Q/B values is slightly lower than the estimate of the relative contribution of capelin to cod growth. The latter values were obtained by comparing annual growth with the estimate of capelin fuelled growth from equation $2\left(0.8 *\left(\mathrm{~W}_{\mathrm{t}}-1300 \mathrm{~g}\right)\right)$. This calculation suggests that capelin contributed between $28.1-34.5 \%$ of the annual growth of the cod compared to the $10.1-33.3 \%$ contribution to annual food consumption. The annual growth of age classes 3 to 6 years was 382.2 g. This is higher than the growth of the same age classes in the nearby East and West Greenland (167 g), Labrador/Grand Bank (350 g) and Northern Gulf of St. Lawrence (220 g) populations living 
at comparable temperatures (Brander, 1995). Therefore, the higher relative contribution of capelin to growth is likely not due to an underestimation of annual growth in the Godthaabsfjord cod. Given the positive relation between temperature and Q/B (Palomares and Pauly, 1989) and the fact that the lowest $\mathrm{Q} / \mathrm{B}$ value in Pauly (1989) was from cod in Northern Norway living at $5{ }^{\circ} \mathrm{C}$, it is likely that the contribution of capelin to annual prey consumption is at the higher range of $10.1-33.3 \%$ and therefore close to the estimates for the contribution to annual growth.

Despite a potential $30 \%$ contribution to annual consumption and growth, this is still considerably lower than the $60 \%$ contribution to consumption estimated by Bundy et al. (2000) using a massbalance model for cod on the Newfoundland-Labrador shelf. However, our consumption estimates could potentially be underestimated. Any diet study based on active fishing, e.g. jigging as in the present study, may select for individuals with a certain behaviour. It is reasonable to assume that hungry individuals are more likely to be caught than satiated fishes (Løkkeborg et al., 2014). This would tend to bias the stomach prey biomass downwards and during gorge feeding on capelin the active fishing technique may actually miss the cod that have the most capelin in the stomach.

The isotope based approach to estimate ingestion is based on three main assumptions. First, we use a trophic enrichment of 3.2\%o (Sweeting et al., 2007a), which is known to vary with e.g. prey type and predator growth rate (Vanderklift and Ponsard, 2003; Trueman et al., 2005; Barnes et al., 2n07). We therefore tested the sensitivity of the calculations to variation in this. Trophic enrichments of $2.9 \%$ and $3.5 \%$ o changed the estimated consumption based on male muscle isotope values from the original $658.8 \mathrm{~g}$ to $877.0 \mathrm{~g}$ and $525.6 \mathrm{~g}$, respectively. Similarly, we use a net growth efficiency of 0.4 in our calculations of $c$. Changing the net growth efficiency to 0.3 and 0.5 yields consumption estimates of $854.0 \mathrm{~g}$ and $476.0 \mathrm{~g}$. Although the model show variation in response to the uncertainty in these two important parameters, a realistic range of trophic enrichments and net growth efficiencies do not alter the conclusions from the modelling substantially. A third point is that the model is based only on capelin and euphausiids ignoring 
other prey consumed during this period. However, these two prey groups contribute $94.8 \%$ of the consumption in May and June, thus it is not likely that the inclusion of the minor prey groups will affect the results significantly.

There is a wealth of evidence for the importance of capelin for cod growth, reproduction and population dynamics and the collapses of capelin populations have been implicated in the collapse and lack of rebuilding of major cod populations (Marshall et al., 1999; Gjøsæter et al., 2009; Mullowney and Rose, 2014; Rose and Rowe, 2015). The present study adds yet another population to the list of cod populations for which capelin is a crucial food source.

Despite the large size of the Godthaabsfjord, the small fjord arm of Kapissilt is by far the largest spawning area for Godthaabsfjord cod and has been so over at least the last century (Smidt, 1979; Swalethorp et al., 2016). We speculate that the tight spatial and temporal overlap between spawning cod and capelin might be key to the success of the Kapissilit spawning area. The overlap enables cod to increase energy intake around spawning time to assure quality of the eggs and increase reproductive output (Rideout et al., 2005; Røjbek et al., 2012) or replenish energy stores immediately after reproduction (Link and Burnett, 2001; Smith et al., 2007). This rapid replenishment may counteract increased mortality observed in response to poor condition following spawning (Dutil and Lambert, 2000; Lambert and Dutil, 2000). Consequently, the importance of capelin may extend beyond their contribution to the overall energy budget and be more related to the timing of the consumption, that allows enhanced reproduction and subsequent improved survival of the Godthaabsfjord cod.

Author contributions 
PG, EEN and RH conceived and designed the research. RH performed sampling. RO and TJ performed laboratory work. PG, RO and LR analysed the data. PG and RO wrote an early draft and completed it with significant inputs from all authors. EEN and PG secured funding.

\section{Significance statement}

Seasonal prey bursts are important for the lifecycles and energy budgets of many predators. Here we use stomach content analysis and stable isotopes to estimate the importance of the ephemeral occurrence of spawning capelin as prey for Atlantic cod (Gadus morhua) in Godthaabsfjord, west Greenland. We estimate that capelin intake during May corresponds to $10.1-33.3 \%$ of the annual food consumption and hypothesize that capelin is critical for the post-spawning recovery of Godthaabsfjord cod. 


\section{References}

Ahlbeck, I., Hansson, S., Hjerne, O., \& Ramcharan, C. W. (2012). Evaluating fish diet analysis methods by individual-based modelling. Canadian Journal of Fisheries and Aquatic Sciences 69, 1184-1201.

Ankjærø, T., Christensen, J. T., \& Grønkjær, P. (2012). Tissue-specific turnover rates and trophic enrichment of stable $\mathrm{N}$ and $\mathrm{C}$ isotopes in juvenile Atlantic cod Gadus morhua fed three different diets. Marine Ecology Progress Series 461, 197-209.

Armstrong, J. B., \& Schindler, D. E. (2011). Excess digestive capacity in predators reflects a life of feast and famine. Nature 476, 84-+.

Barnes, C., Sweeting, C. J., Jennings, S., Barry, J. T., \& Polunin, N. V. C. (2007). Effect of temperature and ration size on carbon and nitrogen stable isotope trophic fractionation. Functional Ecology 21, 356-362.

Bjørke, H. (2001). Predators of the squid Gonatus fabricii (Lichtenstein) in the Norwegian Sea. Fisheries Research 52, 113-120.

Blicher, M. E., Rysgaard, S., \& Sejr, M. K. (2010). Seasonal growth variation in Chlamys islandica (Bivalvia) from sub-Arctic Greenland is linked to food availability and temperature. Marine Ecology Progress Series 407, 71-86.

Bogetveit, F. R., Slotte, A., \& Johannessen, A. (2008). The ability of gadoids to take advantage of a shortterm high availability of forage fish: the example of spawning aggregations in Barents Sea capelin. Journal of Fish Biology 72, 1427-1449.

Bonanomi, S., Pellissier, L., Therkildsen, N. O., Hedeholm, R. B., Retzel, A., Meldrup, D., Olsen, S. M., Nielsen, A., Pampoulie, C., Hemmer-Hansen, J., Wisz, M. S., Grønkjær, P., \& Nielsen, E. E. (2015). Archived DNA reveals fisheries and climate induced collapse of a major fishery. Sci Rep 5, 15395.

Brander, K. M. (1995). The effect of temperature on growth of Atlantic cod (Gadus morhua L.). Ices Journal of Marine Science 52, 1-10.

Bundy, A., Lilley, R. J., \& Shelton, P. A. (2000). A mass balance model of the Newfoundland-Labrador Shelf. In Canadian Technical Report of Fisheries and Aquatic Sciences, p. 157.

Dalpadado, P., \& Bogstad, B. (2004). Diet of juvenile cod (age 0-2) in the Barents Sea in relation to food availability and cod growth. Polar Biology 27, 140-154.

Doucette, J. L., Wissel, B., \& Somers, C. M. (2010). Effects of Lipid Extraction and Lipid Normalization on Stable Carbon and Nitrogen Isotope Ratios in Double-crested Cormorants: Implications for Food Web Studies. Waterbirds 33, 273-284.

Dutil, J. D., \& Lambert, Y. (2000). Natural mortality from poor condition in Atlantic cod (Gadus morhua). Canadian Journal of Fisheries and Aquatic Sciences 57, 826-836. 
Enoksen, S. E., \& Reiss, H. (2018). Diet of Norwegian coastal cod (Gadus morhua) studied by using citizen science. Journal of Marine Systems 180, 246-254.

Frandsen, R. P., \& Wieland, K. (2004). Cephalopods in Greenland Waters. In Technical Report, p. 19: Pinngortitaleriffik, Greenland Institute of Natural Resources.

Frank, K. T., Petrie, B., Choi, J. S., \& Leggett, W. C. (2005). Trophic cascades in a formerly cod-dominated ecosystem. Science 308, 1621-1623.

Friis-Rødel, E., \& Kanneworff, P. (2002). A review of capelin (Mallotus villosus) in Greenland waters. Ices Journal of Marine Science 59, 890-896.

Gjøsæter, H., Bogstad, B., \& Tjelmeland, S. (2009). Ecosystem effects of the three capelin stock collapses in the Barents Sea. Marine Biology Research 5, 40-53.

Hawkins, A. D., Soofiani, N. M., \& Smith, G. W. (1985). Growth and Feeding of Juvenile Cod (Gadus morhua L). Journal Du Conseil 42, 11-32.

Hedeholm, R., Grønkjær, P., Rosing-Asvid, A., \& Rysgaard, S. (2010). Variation in size and growth of West Greenland capelin (Mallotus villosus) along latitudinal gradients. Ices Journal of Marine Science 67, 11281137.

Hedeholm, R. B., Mikkelsen, J. H., Svendsen, S. M., Carl, J., \& Jensen, K. T. (2017). Atlantic cod (Gadus morhua) diet and the interaction with northern shrimp (Pandalus borealis) in Greenland waters. Polar Biology 40, 1335-1346.

Johannesen, E., Lindstrom, U., Michalsen, K., Skern-Mauritzen, M., Fauchald, P., Bogstad, B., \& Dolgov, A. (2012). Feeding in a heterogeneous environment: spatial dynamics in summer foraging Barents Sea cod. Marine Ecology Progress Series 458, 181-197.

Juul-Pedersen, T., Arendt, K. E., Mortensen, J., Blicher, M. E., Sogaard, D. H., \& Rysgaard, S. (2015). Seasonal and interannual phytoplankton production in a sub-Arctic tidewater outlet glacier fjord, SW Greenland.

Marine Ecology Progress Series 524, 27-38.

Kjesbu, O. S., Witthames, P. R., Solemdal, P., \& Walker, M. G. (1998). Temporal variations in the fecundity of Arcto-Norwegian cod (Gadus morhua) in response to natural changes in food and temperature. Journal of Sea Research 40, 303-321.

Knickle, D. C., \& Rose, G. A. (2014). Dietary niche partitioning in sympatric gadid species in coastal Newfoundland: evidence from stomachs and C-N isotopes. Environmental Biology of Fishes 97, 343-355.

Knutsen, I., \& Salvanes, A. G. V. (1999). Temperature-dependent digestion handling time in juvenile cod and possible consequences for prey choice. Marine Ecology Progress Series 181, 61-79.

Kristensen, T. K. (1977). Hatching, growth, and distribution of juvenile Gonatus fabricii (Mollusca: Cephalopoda) in Greenland waters. Astarte 10, 21-28. 
Krohn, M., Reidy, S., \& Kerr, S. (1997). Bioenergetic analysis of the effects of temperature and prey availability on growth and condition of northern cod (Gadus morhua). Canadian Journal of Fisheries and Aquatic Sciences 54, 113-121.

Krumsick, K. J., \& Rose, G. A. (2012). Atlantic cod (Gadus morhua) feed during spawning off Newfoundland and Labrador. Ices Journal of Marine Science 69, 1701-1709.

Kuklinski, P., Berge, J., McFadden, L., Dmoch, K., Zajaczkowski, M., Nygard, H., Piwosz, K., \& Tatarek, A. (2013). Seasonality of occurrence and recruitment of Arctic marine benthic invertebrate larvae in relation to environmental variables. Polar Biology 36, 549-560.

Lambert, Y., \& Dutil, J. D. (2000). Energetic consequences of reproduction in Atlantic cod (Gadus morhua) in relation to spawning level of somatic energy reserves. Canadian Journal of Fisheries and Aquatic Sciences $57,815-825$.

Lambert, Y., \& Dutil, J. D. (2001). Food intake and growth of adult Atlantic cod (Gadus morhua L.) reared under different conditions of stocking density, feeding frequency and size-grading. Aquaculture 192, 233247.

Link, J. S., Bogstad, B., Sparholt, H., \& Lilly, G. R. (2009). Trophic role of Atlantic cod in the ecosystem. Fish and Fisheries 10, 58-87.

Link, J. S., \& Burnett, J. (2001). The relationship between stomach contents and maturity state for major northwest Atlantic fishes: new paradigms? Journal of Fish Biology 59, 783-794.

Løkkeborg, S., Siikavuopio, S. I., Humborstad, O. B., Utne-Palm, A. C., \& Ferter, K. (2014). Towards more efficient longline fisheries: fish feeding behaviour, bait characteristics and development of alternative baits. Reviews in Fish Biology and Fisheries 24, 985-1003.

Loreau, M., \& Holt, R. D. (2004). Spatial flows and the regulation of ecosystems. American Naturalist 163, 606-615.

Magnussen, E. (2011). Food and feeding habits of cod (Gadus morhua) on the Faroe Bank. Ices Journal of Marine Science 68, 1909-1917.

Marshall, C. T., Yaragina, N. A., Lambert, Y., \& Kjesbu, O. S. (1999). Total lipid energy as a proxy for total egg production by fish stocks. Nature 402, 288-290.

Mattson, S. (1990). Food and Feeding-Habits of Fish Species over a Soft Sublittoral Bottom in the Northeast Atlantic .1. Cod (Gadus morhua L) (Gadidae). Sarsia 75, 247-260.

Maxner, E., Halden, N. M., Roth, J. D., \& Davoren, G. K. (2016). Intrinsic factors influence the timing of arrival of capelin (Mallotus villosus) to spawning grounds in coastal Newfoundland. Fisheries Research 179, 202-212. 
McCormick, M. I. (2003). Consumption of coral propagules after mass spawning enhances larval quality of damselfish through maternal effects. Oecologia 136, 37-45.

McMeans, B. C., McCann, K. S., Humphries, M., Rooney, N., \& Fisk, A. T. (2015). Food Web Structure in Temporally-Forced Ecosystems. Trends in Ecology \& Evolution 30, 662-672.

Michalsen, K., Johannesen, E., \& Bogstad, L. (2008). Feeding of mature cod (Gadus morhua) on the spawning grounds in Lofoten. Ices Journal of Marine Science 65, 571-580.

Mullowney, D. R. J., \& Rose, G. A. (2014). Is recovery of northern cod limited by poor feeding? The capelin hypothesis revisited. Ices Journal of Marine Science 71, 784-793.

Naiman, R. J., Bilby, R. E., Schindler, D. E., \& Helfield, J. M. (2002). Pacific salmon, nutrients, and the dynamics of freshwater and riparian ecosystems. Ecosystems 5, 399-417.

Newsome, S. D., del Rio, C. M., Bearhop, S., \& Phillips, D. L. (2007). A niche for isotopic ecology. Frontiers in Ecology and the Environment 5, 429-436.

Nielsen, J. R., \& Andersen, M. (2001). Feeding Habits and Density Patterns of Greenland Cod, Gadus ogac (Richardson 1836), at West Greenland compared to Those of the Coexisting Cod, Gadus morhua L. Journal of Northwest Atlantic Fishery Science 30, 1-22.

Palomares, M. L., \& Pauly, D. (1989). A Multiple-Regression Model for Predicting the Food-Consumption of Marine Fish Populations. Australian Journal of Marine and Freshwater Research 40, 259-273.

Pálsson, O. K., \& Björnsson, H. (2011). Long-term changes in trophic patterns of Iceland cod and linkages to main prey stock sizes. Ices Journal of Marine Science 68, 1488-1499.

Pauly, D. (1989). Food-Consumption by Tropical and Temperate Fish Populations - Some Generalizations. Journal of Fish Biology 35, 11-20.

Piatkowski, U., \& Wieland, K. (1993). The Boreoatlantic gonate squid Gonatus fabricii: distribution and size off West Greenland in summer 1989 and in summer and autumn 1990. Aquatic Living Resources 6, 109-114.

Polis, G. A., Anderson, W. B., \& Holt, R. D. (1997). Toward an integration of landscape and food web ecology: The dynamics of spatially subsidized food webs. Annual Review of Ecology and Systematics 28, 289-316.

R Core Team (2018). R: A Language and Environment for Statistical Computing. R Foundation for Statistical Computing, Vienna.

Rideout, R. M., Rose, G. A., \& Burton, M. P. M. (2005). Skipped spawning in female iteroparous fishes. Fish and Fisheries 6, 50-72.

Røjbek, M. C., Jacobsen, C., Tomkiewicz, J., \& Støttrup, J. G. (2012). Linking lipid dynamics with the reproductive cycle in Baltic cod Gadus morhua. Marine Ecology Progress Series 471, 215-234. 
Røjbek, M. C., Støttrup, J. G., Jacobsen, C., Tomkiewicz, J., Nielsen, A., \& Trippel, E. A. (2014). Effects of dietary fatty acids on the production and quality of eggs and larvae of Atlantic cod (Gadus morhua L.). Aquaculture Nutrition 20, 654-666.

Rose, G. A., \& O'Driscoll, R. L. (2002). Capelin are good for cod: can the northern stock rebuild without them? Ices Journal of Marine Science 59, 1018-1026.

Rose, G. A., \& Rowe, S. (2015). Northern cod comeback. Canadian Journal of Fisheries and Aquatic Sciences $72,1789-1798$.

Schwalme, K., \& Chouinard, G. A. (1999). Seasonal dynamics in feeding, organ weights, and reproductive maturation of Atlantic cod (Gadus morhua) in the southern Gulf of St Lawrence. Ices Journal of Marine Science 56, 303-319.

Sheffield, G., Fay, F. H., Feder, H., \& Kelly, B. P. (2001). Laboratory digestion of prey and interpretation of walrus stomach contents. Marine Mammal Science 17, 310-330.

Sherwood, G. D., Rideout, R. M., Fudge, S. B., \& Rose, G. A. (2007). Influence of diet on growth, condition and reproductive capacity in Newfoundland and Labrador cod (Gadus morhua): Insights from stable carbon isotopes $\left(\delta^{13} \mathrm{C}\right)$. Deep Sea Research Part II: Topical Studies in Oceanography 54, 2794-2809.

Sherwood, G. D., \& Rose, G. A. (2005). Stable isotope analysis of some representative fish and invertebrates of the Newfoundland and Labrador continental shelf food web. Estuarine Coastal and Shelf Science 63, 537549.

Smidt, E. L. B. (1979). Annual cycles of primary production and of zooplankton at Southwest Greenland. Copenhagen: Museum Tusculanum Press.

Smith, B. E., Ligenza, T. J., Almeida, F. P., \& Link, J. S. (2007). The trophic ecology of Atlantic cod: insights from tri-monthly, localized scales of sampling. Journal of Fish Biology 71, 749-762.

Swalethorp, R., Kjellerup, S., Malanski, E., Munk, P., \& Nielsen, T. G. (2014). Feeding opportunities of larval and juvenile cod (Gadus morhua) in a Greenlandic fjord: temporal and spatial linkages between cod and their preferred prey. Marine Biology 161, 2831-2846.

Swalethorp, R., Nielsen, T. G., Thompson, A. R., Mohl, M., \& Munk, P. (2016). Early life of an inshore population of West Greenlandic cod Gadus morhua: spatial and temporal aspects of growth and survival. Marine Ecology Progress Series 555, 185-202.

Sweeting, C. J., Barry, J., Barnes, C., Polunin, N. V. C., \& Jennings, S. (2007a). Effects of body size and environment on diet-tissue $\delta^{15} \mathrm{~N}$ fractionation in fishes. Journal of Experimental Marine Biology and Ecology 340, 1-10.

Sweeting, C. J., Barry, J. T., Polunin, N. V. C., \& Jennings, S. (2007b). Effects of body size and environment on diet-tissue $\delta^{13} \mathrm{C}$ fractionation in fishes. Journal of Experimental Marine Biology and Ecology 352, 165-176. 
Tarpgaard, E., Mogensen, M., Grønkjær, P., \& Carl, J. (2005). Using short-term growth of enclosed 0-group European flounder, Platichthys flesus, to assess habitat quality in a Danish bay. Journal of Applied Ichthyology 21, 53-63.

Temming, A., \& Herrmann, J. P. (2003). Gastric evacuation in cod - Prey-specific evacuation rates for use in North Sea, Baltic Sea and Barents Sea multi-species models. Fisheries Research 63, 21-41.

Therkildsen, N. O., Hemmer-Hansen, J., Hedeholm, R. B., Wisz, M. S., Pampoulie, C., Meldrup, D., Bonanomi, S., Retzel, A., Olsen, S. M., \& Nielsen, E. E. (2013). Spatiotemporal SNP analysis reveals pronounced biocomplexity at the northern range margin of Atlantic cod Gadus morhua. Evolutionary Applications 6, 690-705.

Trueman, C. N., McGill, R. A. R., \& Guyard, P. H. (2005). The effect of growth rate on tissue-diet isotopic spacing in rapidly growing animals. An experimental study with Atlantic salmon (Salmo salar). Rapid Communications in Mass Spectrometry 19, 3239-3247.

van Deurs, M., Persson, A., Lindegren, M., Jacobsen, C., Neuenfeldt, S., Jorgensen, C., \& Nilsson, P. A. (2016). Marine ecosystem connectivity mediated by migrant-resident interactions and the concomitant cross-system flux of lipids. Ecology and Evolution 6, 4076-4087.

Vandeperre, F., \& Methven, D. A. (2007). Do bigger fish arrive and spawn at the spawning grounds before smaller fish: Cod (Gadus morhua) predation on beach spawning capelin (Mallotus villosus) from coastal Newfoundland. Estuarine Coastal and Shelf Science 71, 391-400.

Vanderklift, M. A., \& Ponsard, S. (2003). Sources of variation in consumer-diet $\delta^{15} \mathrm{~N}$ enrichment: a metaanalysis. Oecologia 136, 169-182.

Waiwood, K. G., Smith, S. J., \& Petersen, M. R. (1991). Feeding of Atlantic Cod (Gadus morhua) at Low Temperatures. Canadian Journal of Fisheries and Aquatic Sciences 48, 824-831.

Willson, M. F., \& Womble, J. N. (2006). Vertebrate exploitation of pulsed marine prey: a review and the example of spawning herring. Reviews in Fish Biology and Fisheries 16, 183-200.

Worm, B., \& Myers, R. A. (2003). Meta-analysis of cod-shrimp interactions reveals top-down control in oceanic food webs. Ecology 84, 162-173.

Yang, L. H., Bastow, J. L., Spence, K. O., \& Wright, A. N. (2008). What can we learn from resource pulses? Ecology 89, 621-634.

Yaragina, N. A., \& Marshall, C. T. (2000). Trophic influences on interannual and seasonal variation in the liver condition index of Northeast Arctic cod (Gadus morhua). Ices Journal of Marine Science 57, 42-55. 


\section{Figure legends}

Figure 1: Sampling location. Map of southern Greenland with insert showing the sampling location at Kapissilit in the Godthaabsfjord system.

Figure 2: The Godthaabsfjord cod (Gadus morhua) diet. Figure 2a shows the proportion of females in the sample at each sampling date. Figure $2 b$ is the proportion (by AFDW) of pelagic prey in the diet (full line) and the Shannon diversity index (stippled line) at each date. These indexes could not be calculated for $5^{\text {th }}$ January 2011 as these only contained highly digested matter. Figure $2 \mathrm{~b}$ shows the sex specific AFDW (g) of the stomach content normalised to a fish of $1 \mathrm{~kg}$ dressed weight.

Figure 3: Clustering of sampling dates. Clustering of sampling dates based on Brey-Curtis similarities of untransformed AFDW of stomach content. All groups from Table 1 except "Unknown material" are included in the analysis. 


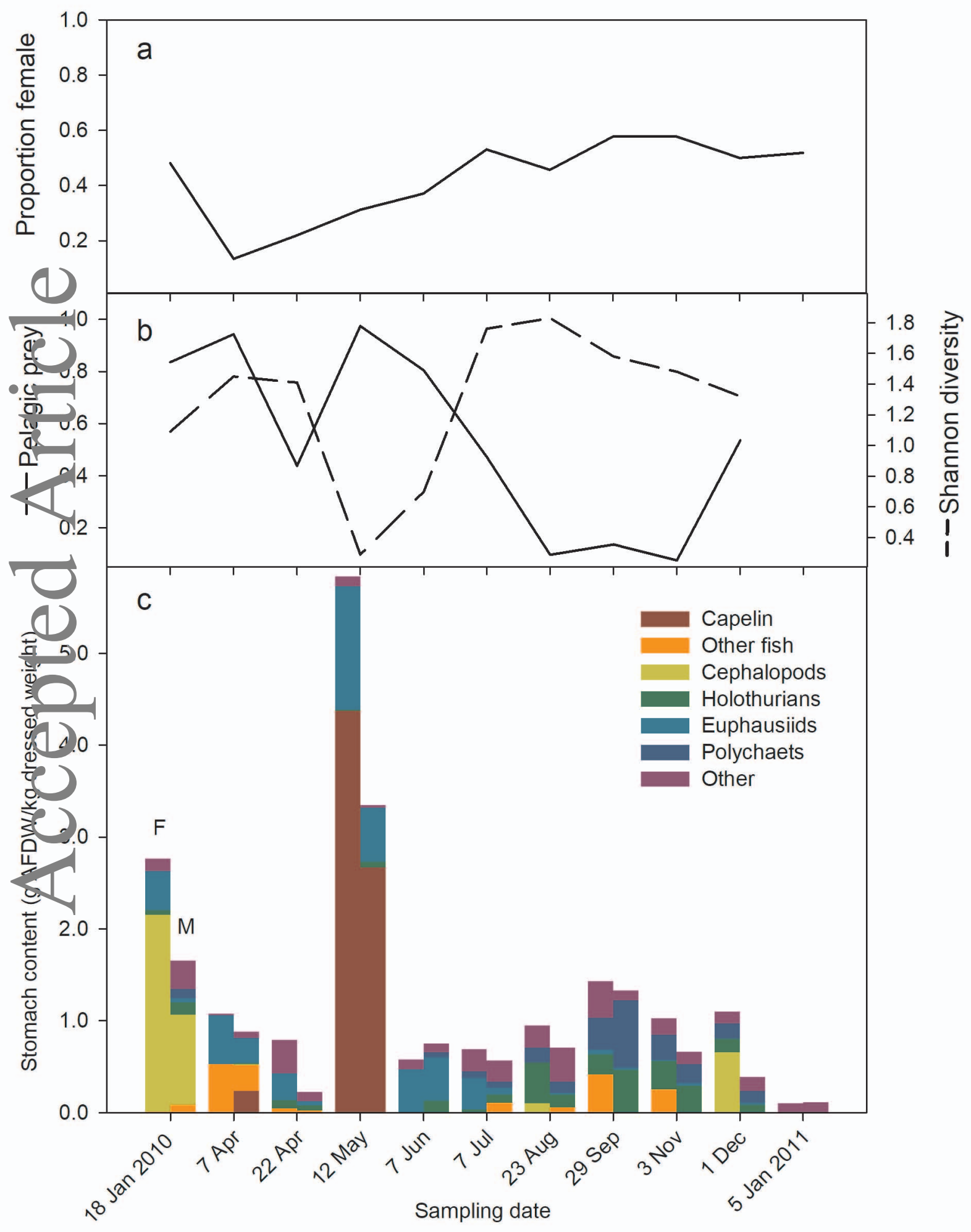




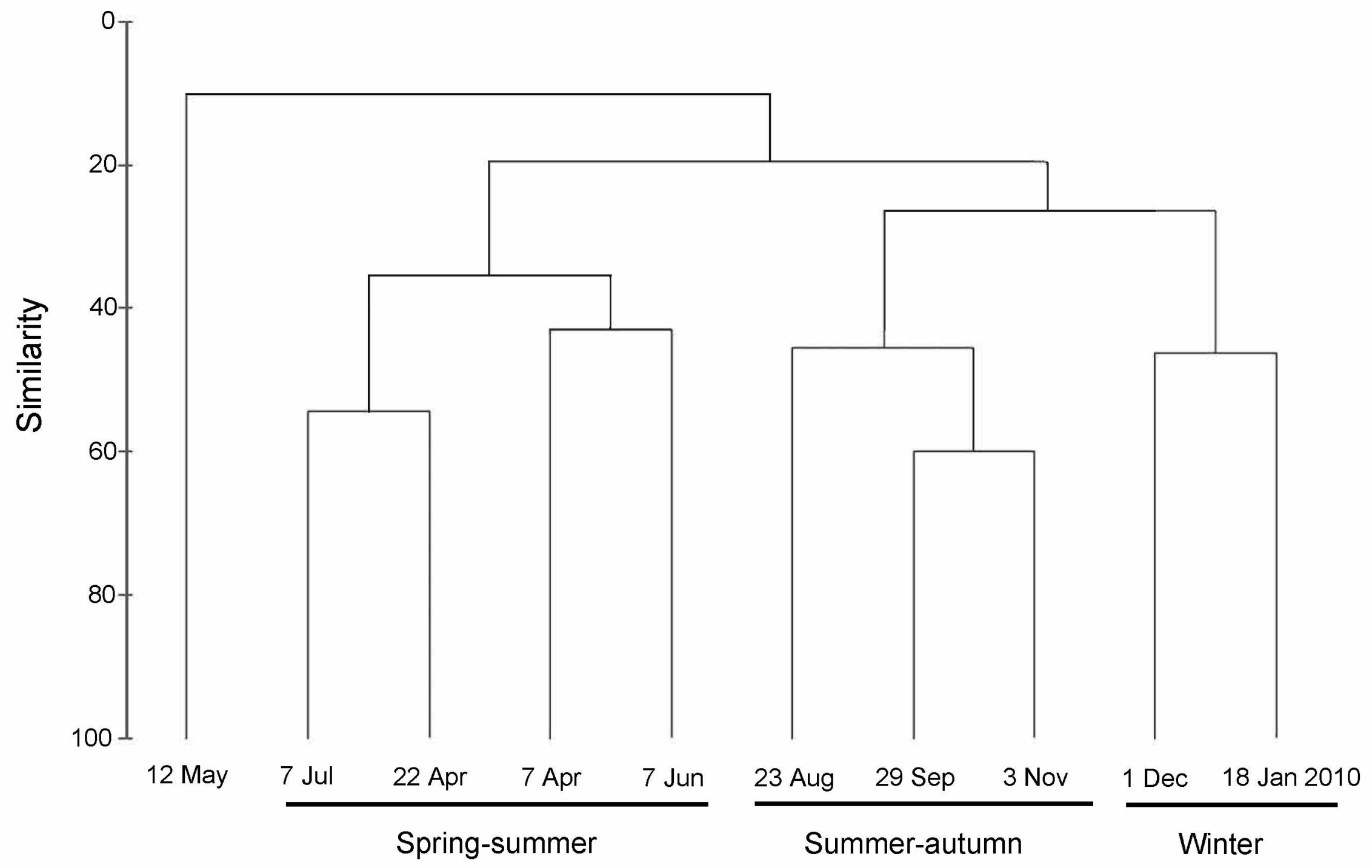


Table I: The ash free dry weight (AFDW, g) of the different prey groups at each sampling date. *Empty is defined as only containing unknown highly digested material. Species names followed by ${ }^{\#}$ indicates pelagic prey.

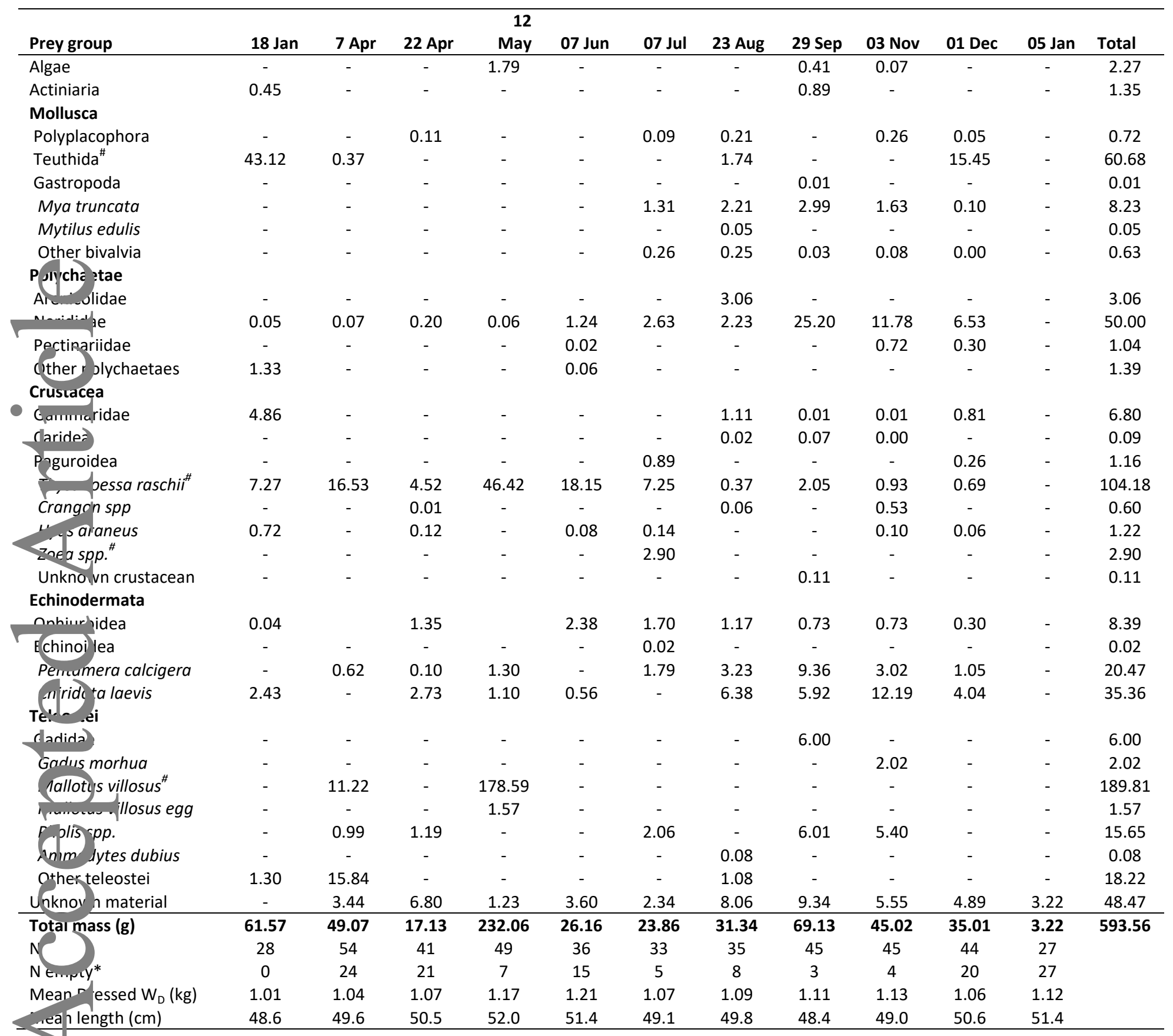


